decrease of $5 \%$ is suggested by Leitch, and for potatoes, fruit and vegetables (excluding legumes) a decrease of $8 \%$ compared with our increase of $30 \%$. Leitch's estimate for meat, fish and eggs would reduce consumption to about that in $194 \mathrm{I}$, the worst period of the war. The differences are doubtless due to differences in selection of the kinds and amounts of foods whereby the targets set for nutrients by the League of Nations could be reached. We regarded as fundamental the satisfaction of the public taste and this obviously could not be achieved in these islands without liberal amounts of meat, fish and eggs. Since Leitch's estimates for these foods are far below ours, it would seem that she attached less importance to this criterion than we have done.

Our procedure was governed by two important assumptions, that there would be no rationing, and that nobody would obtain more or less than the quantities we had allotted to them. Without strict rationing, the latter would not apply and consumption would be influenced by factors such as income. It would, therefore, be necessary to provide more of the nutritious and dietetically desirable foods than the estimates in Table 5 allow. These considerations raise questions of a social and economic nature which might well form the subject of a future symposium of the Society.

\title{
REFERENCES
}

Accessory Food Factors Committee (1945). War Memor. med. Res. Coun., Lond., no. 14.

Advisory Committee on Nutrition, Ministry of Health (1937). First Report. London: H.M. Stationery Office.

Bransby, E. R. \& Magee, H. E. (1947). Brit. med. F. i, 525.

Food and Agriculture Organization of the United Nations (1946). World Food Survey. Washington: Food and Agriculture Organization of the United Nations.

International Labour Office (1938). The Worker's Standard of Living. Geneva: International Labour Office.

Leitch, I. (1944). Proc. Nutr. Soc. I, 60.

Magee, H. E. (1 943). Publ. Hlth, Lond., 56, 126.

Ministry of Food (1947). Food Consumption Levels in United Kingdom [Cmd. 7203]. London: H.M. Stationery Office.

Mixed Committee on the Problem of Nutrition (1936). Interim Report. League of Nations: A. I2. 1936. II. $\mathrm{B}$.

Technical Commission of the Health Committee (1936). Report on the Physiological Bases of Nutrition. League of Nations: A. I2 (a). I936. II. B.

Technical Commission on Nutrition (1938). Bull. Hlth Org. L.o.N. 7, 460.

West Riding of Yorkshire County Council (1939). Report on the Study of Diets of 205 Families in the West Riding of Yorkshire. Wakefield: -West Riding of Yorkshire County Council.

\section{Home Production of Wheat, Potatoes and Sugar-beet}

\author{
By E. T. Jones, Welsh Plant Breeding Station, Aberystwyth
}

Home production in 1946

Taking 1946 as a basic year, the estimated quantities of wheat, potatoes and sugar-beet harvested in the United Kingdom in that year, as given by the Central Statistical Office (1947), were $1,967,000,10,166,000$ and 4,522,000 t. respectively. To arrive at the net amounts available as food for human consumption, deductions have to be made for seed and screenings of wheat and potatoes retained on the farm, the sugar-beet total 
has to be translated into terms of sugar, and the available wheat into its equivalent as flour. In calculating the proportions which these net amounts contribute towards the total needs, the 1946 figures of estimated total needs as given by Bransby, Magee, Bowley $\&$ Stanton (1947), namely, 4,202,000, 5,890,000 and r,936,000 metric t. of grain (as flour), potatoes and sugar, respectively, have been used. The latter figures, converted into cwt., and the net home-production figures with their equivalent values in terms of proteins, calcium and calories are presented in Table $\mathrm{I}$.

Table I. Comparison of home-produced wheat (as flour), of potatoes and of sugar-beet (as sugar) and of their protein, calcium and calorie values with stipulated total needs

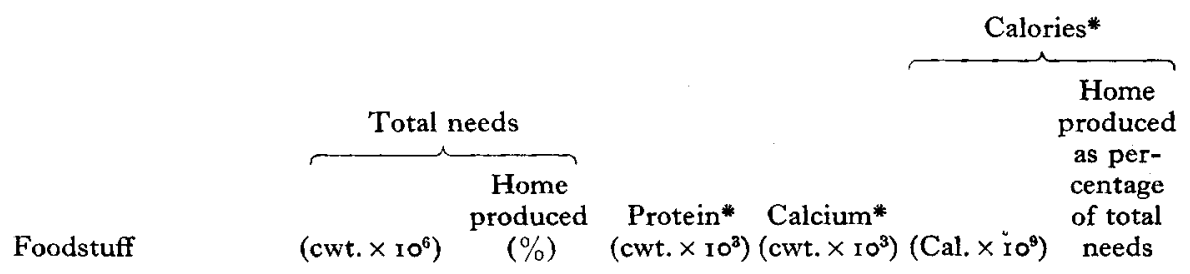

Wheat (as flour of $85 \% \mathrm{ex}$ traction, fortified):

Total needs

Home produced (net)

Potatoes (as purchased):

Total needs

Home produced (net)

Sugar-beet (as white sugar):

Total needs

Home produced

\begin{tabular}{|c|c|c|c|c|}
\hline $\begin{array}{l}82 \cdot 73 t \\
29 \cdot 14 t\end{array}$ & $35^{\circ}$ & $\begin{array}{l}7280 \\
2563\end{array}$ & $\begin{array}{l}72 \cdot 8 \\
25 \cdot 6\end{array}$ & $\begin{array}{r}14412 \dagger \\
5073 \dagger\end{array}$ \\
\hline I I $5.96 \dagger$ & - & I 739 & $6 \cdot 96$ & $3239 \uparrow$ \\
\hline I $45^{\circ} 22 \oint$ & $125 \cdot 2$ & 2177 & $8 \cdot 71$ & $4055 \S$ \\
\hline $3^{8 \cdot 12 \dagger}$ & - & 一 & - & $7356 \dagger$ \\
\hline I $3.19 \|$ & $34 \cdot 6$ & $\ldots$ & - & $2544 \|$ \\
\hline
\end{tabular}

$45 \cdot 7$

* Based on Nutritive Values of Wartime Foods (Accessory Food Factors Committee, 1945): Flour: $8.8 \mathrm{~g}$. protein, $88 \mathrm{mg}$. calcium, and $343 \mathrm{Cal} / \mathrm{l} 00 \mathrm{~g}$. Potatoes: $1.5 \mathrm{~g}$. protein, $6 \mathrm{mg}$. calcium, and $55 \mathrm{Cal} / \mathrm{1} 00 \mathrm{~g}$. Sugar: $1.5 \mathrm{~g}$. protein, $6 \mathrm{mg}$. calcium, and $380 \mathrm{Cal} / \mathrm{r} 00 \mathrm{~g}$.

$\uparrow$ Calculated from figures by Bransby et al. (1947).

I After deduction of $\mathrm{I} \cdot 5 \mathrm{cwt}$./acre for seed, $5 \%$ of gross yield as screenings and $15 \%$ milling offals.

$\$$ After deduction of $\frac{2}{7}$ of gross yield for seed and chats (Thomas, 1943).

If Based on average of $1935^{-6}$ and $1936-7$ figures of factory output of white sugar/t. of beet ( 1 t. $=2.92$ cwt. sugar) (Sugar Commission, I937).

Compared with the stipulated dietary needs, which are higher for sugar and lower for flour and potatoes than the actual civilian consumption of these foods in 1946, the percentage contributions of home-produced wheat (as flour), of potatoes and of sugarbeet (as sugar) are $35.2,125.2$ and 34.6 , respectively. In terms of calories, these home supplies provide $46.7 \%$ of the total needs from these sources. To balance our total needs from home resources would require on a pre-war (1934-8) yield basis, a reduction of 223,000 acres in potatoes, and an increase of about 4,000,000 and $1,000,000$ acres respectively in wheat and sugar-beet, making a net increase over the 1946 acreage of nearly 5,000,000 acres ('Table 2 ). 
Table 2. Estimated gross needs of wheat, potatoes and sugar-beet in I946 and I964 and calculated acreages required to meet total needs on the basis of pre-war yields

\begin{tabular}{|c|c|c|c|c|c|}
\hline $\begin{array}{l}\text { Foodstuff } \\
\text { and year }\end{array}$ & $\begin{array}{l}\text { Estimated } \\
\text { gross needs } \\
\text { (cwt. } \times 10^{6} \text { ) }\end{array}$ & $\begin{array}{r}\text { Pre-war* } \\
\text { yield/acre } \\
\text { (Av. I934-8) }\end{array}$ & $\begin{array}{c}1946 \dagger \\
\text { acreage } \\
\text { (acres } \times 10^{3} \text { ) }\end{array}$ & $\begin{array}{l}\text { Acreage required } \\
\text { to meet gross } \\
\text { needs on pre-war } \\
\text { yield figures } \\
\left(\text { acres } \times 10^{3}\right)\end{array}$ & $\begin{array}{l}\text { Increase or } \\
\text { decrease on } \\
1946 \text { acreage } \\
\left(\text { acres } \times 10^{3}\right)\end{array}$ \\
\hline \multicolumn{6}{|l|}{ I 946} \\
\hline Wheat & I I I 76 & I $8.4 \mathrm{cwt}$. & 2062 & 6074 & 4012 \\
\hline Potatoes & $162 \cdot 06$ & $6 \cdot 7 \mathrm{t}$ & 1432 & 1209 & -223 \\
\hline Sugar-beet & $257 \cdot 60$ & $8 \cdot 8 \mathrm{t}$ & 436 & 1464 & 1028 \\
\hline $\begin{array}{l}\text { Total } \\
\text { I964 }\end{array}$ & - & - & $393^{\circ}$ & 8747 & 4817 \\
\hline Wheat & 119.22 & As above & As above & 6479 & 4417 \\
\hline Potatoes & $174 \cdot 08$ & As above & As above & 1299 & -133 \\
\hline Sugar-beet & $273 \cdot 26$ & As above & As above & I 553 & III7 \\
\hline Total & 一 & 一 & 3930 & 9331 & 5401 \\
\hline
\end{tabular}

\section{Estimated requirements for 1964}

The estimated needs for 1964 as submitted by Bransby et al. namely, 4,507,000, $6,316,000$ and $2,056,000$ metric t. of grain (as flour), potatoes and sugar, respectively, would on the same basis of calculation require approximately 600,000 acres supplementary to the calculated area required to meet the 1946 total requirements (Table 2).

\section{Home resources}

It would generally be agreed that with adequate and appropriate facilities, the presentday food production level could be quite materially raised without introducing any fundamental changes in the existing systems of farming. Any effort, however, designed to effect a major drive towards maximum self-sufficiency would, if it were to succeed, involve big changes in our pre-war stock-to-crop balance, cropping sequences and varied systems of farming.

\section{Limitations of acreage}

The area of land suitable for tillage cropping is limited, and any extension of the acreage of wheat, potatoes and sugar-beet would be at the expense of land now devoted to other crops and stock. While extensions are feasible, it is desirable in the first place to explore what can be done by improving the yields and making changes in the relative proportions devoted to each crop within the 1946 acreage.

\section{Means of increasing the yield/acre}

Potatoes. This crop presents no problems. At the pre-war yield of $6.7 \mathrm{t}$./acre, there is an excess, compared with basic needs, of $25.2 \%$. In the Lord Derby Gold Medal Trials reported by Bryan (1935-9 $a, b, c, d$ ) the standard main-crop control varieties averaged $10.87 \mathrm{t}$./acre. By an over-all improvement in cultural technique it should be 
possible to raise the main-crop yields to Io $t$./acre. At this level, total needs could be met by the produce of 810,000 acres, thereby releasing 622,000 acres for the growing of wheat or sugar-beet.

Sugar-beet. Adding the 622,000 acres, surplus from potatoes to the 1946 area under sugar-beet makes a total of $I, 058,000$ acrès. To produce the 1946 basic needs of sugar on this acreage, it would be necessary to raise the yield level to $12.17 \mathrm{t}$./acre. This is not an impossible target on a restricted area but would be difficult to achieve over an expanded acreage. In a 5 years' series (1934-8) of sugar-beet trials at Newport, Cannington and Sprowston reported by Armstrong (1931-4, 1935-9a,b), the control variety gave an average of $14.69 \mathrm{t}$./acre. At the present time any big increase in beet growing is restricted by the limited capacity of the factories processing beet. As a provisional target the 1946 acreage could be extended to 600,000 , and I $t$. taken as an objective in yield/acre. This increase should present no real difficulty and, while providing for $5 \mathrm{I} \%$ of the 1946 estimated needs of sugar, would leave 458,000 acres for the growing of wheat.

Wheat. The carry-over of $45^{8,000}$ acres added to the 1946 wheat acreage gives a total of $2,520,000$ acres. Taking as a first objective the production of $50 \%$ of our estimated needs, this task could be achieved on the available area by raising the level of yield to $22.17 \mathrm{cwt}$./acre. During the peak year of wartime wheat production, the acreage under wheat was $3,464,000$ acres and the estimated yield $18.7 \mathrm{cwt}$./acre. There has been, with the exception of the I9I4-23 period, a steady rise in the yields of wheat since 1877 as the following figures (cwt./acre) for Great Britain (Ministry of Agriculture and Fisheries, 1887-1944) show: 1887-93, 16.16; 1894-1903, 17.15; 1904-13, 17.54; 1914-23, 17.29; 1924-33, 17.64; 1934-8, 18.36; 1939-44, 19.05. In trials reported by Armstrong (I $93 \mathrm{I}-4)$ the average yield of the standard control variety at seven centres over a period of 3 years $(1929-3 \mathrm{I})$ was $22.5 \mathrm{cwt}$./acre.

It is estimated that, without any extension of the 1946 total acreage, by increased efficiency and more intensive management our total food needs of potatoes can be produced on a much reduced acreage, and the percentage contribution of bread grains and sugar respectively raised from their 1946 level of $35 \%$ to approximately $50 \%$. These increased contributions are not to be regarded as the maxima which home resources are able to supply.

\section{REFERENCES}

Accessory Food Factors Committee (1945). War Memor. med. Res. Coun., Lond., no. I4.

Armstrong, S. F. (1931-4). F. nat. Inst. agric. Bot. 3, 23.

Armstrong, S. F. (1935-9a). F. nat. Inst. agric. Bot. 4, 97.

Armstrong, S. F. (1935-9b). F. nat. Inst. agric. Bot. 4, 329.

Bransby, E. R., Magee, H. E., Bowley, M. C. \& Stanton, B. R. (1947). Brit. F. Nutrit. $1,275$.

Bryan, H. (1935-9a). F. nat. Inst. agric. Bot. 4, 59.

Bryan, H. (1 $935-9 b)$. F. nat. Inst. agric. Bot. 4, 168.

Bryan, H. (1935-9c). F. nat. Inst. agric. Bot. 4, 298.

Bryan, H. (1935-9d). F. nat. Inst. agric. Bot. 4, 400.

Central Statistical Office (1947). Mon. Dig. Statist. no. 19.

Ministry of Agriculture and Fisheries (1887-1944). Agric. Statist., Lond. (Annual Returns, 1887-1944). Ministry of Agriculture and Fisheries (1938). Agric. Statist., Lond., 73, part 1.

Sugar Commission (1937). Report for the Year ended 31st March I937, appendix 3. London: H.M. Stationery Office.

Thomas, W. J. (1943). Costs of Production of Cereals, Roots and Forage Crops (mimeo). University College of Wales, Aberystwyth: Agricultural Economics Department. 